\title{
Pengaruh Komitmen dan Disiplin Terhadap Kinerja Pegawai pada Dinas Perhubungan Provinsi Jambi
}

\author{
Oleh: \\ Pratiwi Indah Sari \\ FKIP Universitas Batanghari Jambi \\ Pradasari676@gmail.com
}

\begin{abstract}
The purpose of this research is to know the effect of commitment and discipline to the performance of employees at the Department of Transportation Jambi province simultaneously. The results showed, mean class for the respondent rejoinder of commitment variable $\left(X_{1}\right)$ is $85,65 \%$ and mean class for the respondent rejoinder of discipline variable $\left(X_{2}\right)$ is $83,55 \%$, this result show the biggest score of mean class for the respondent rejoinder are commitment variable $\left(X_{1}\right)$. The amount of variables influence the performance of employee commitment to the Department of Transportation Jambi Province amounted to 3.879\%. The influence of variables on the performance of official discipline of Transportation Office of Jambi Province amounted to $2.811 \%$. The effect of variable commitment and discipline to the performance simultaneous of an employee of Transportation Office of Jambi Province amounted to $2.536\left(X_{1}\right)$ and $2.454\left(X_{2}\right)$.
\end{abstract}

\section{Keyword : Commitment, Discipline, Performance, Employee.}

\section{PENDAHULUAN}

Fenomena perubahan mendasar yang dimanifestasikan dengan melahirkan Undang-Undang Nomor 22 Tahun 1999 tentang Pemerintahan Daerah dan Undangundang nomor 43 tahun tahun 1999 tentang Pokok-pokok Kepegawaian telah memberikan arah perubahan dalam penyelenggaraan pemerintahan dan kepegawaian pegawai negeri sipil yang mempunyai implikasi langsung terhadap kesiapan pengembangan sumber daya manusia, dan ketersediaan sumber daya Realitanya banyak organisasi dalam perkembangannya mengalami masalah yang muncul akibat munculnya kelompokkelompok kecil yang tidak membuat organisasi semakin dinamis, melainkan malah menjadikan keruntuhan organisasi tersebut. Perbedaan peran, harapan, kepentingan, interpendensi, dan persepsi para pegawai menjadi sumber konflik internal yang mengancam kelangsungan hidup lainya. 
Sebuah organisasi sudah mulai tidak efektif adalah kalau pegawainya sudah tidak lagi ingin kompak satu sama lain. Seorang eksekutif HRD (Human Resource Department) menceritakan betapa pegawainya masih harus ditakut-takuti dengan absensi kehadiran, agar mau terlibat dalam kegiatan ataupun meeting yang tidak langsung berdampak ke pekerjaan, seperti donasi, fun activities, atau meeting bipartite. Memang, para pegawai tidak sampai saling memukul, baik dari belakang maupun depan, tidak saling menghina ataupun tidak menyatakan tidak percaya satu sama lain.

Namun, bila perlu adanya koordinasi, katakanlah, crash program, pembenahan kantor ataupun program yang sifatnya nonkritikal tetapi perlu "dikeroyok rame-rame", barulah terlihat bahwa komunikasi dan koordinasi seolah sulit sekali diatur dan diimplementasikan ke dalam kegiatan yang terarah. Disinilah sesungguhnya kita bisa menyaksikan ketidakefektifan sebuah organisasi. Banyak sekali ribut-ribut di perusahaan yang diakhiri dengan komentar. Ini hanya masalah komunikasi, karena kita banyak lupa bahwa tidak efektifnya komunikasi merupakan manajemen yang sangat besar.

Hasil dari tidak efektifnya komunikasi adalah pegawai tidak terhubung dengan misi organisasi, merasa tertinggal dalam gelap dan tidak memahami bagaimana berpartisipasi dan melibatkan diri secara sesuai. Tidak efektifnya komunikasi ini, dalam keadaan parah bisa tidak terdeteksi lagi. Yang terlihat justru pada tidak berkomitmennya setiap bagian, individu atau kelompok terhadap apa yang sudah diiyakan, dijanjikan atau direncanakan. Lebih parah lagi, bila komitmen terhadap deadline waktu, kuantitas tidak bisa dinyatakan lagi. Semua rencana dan tindakan hanya bersifat mengambang. Di sinilah kita perlu waspada terhadap matinya spirit perusahaan atau lembaga karena sakitnya komitmen.

Dengan demikian, komitmen organisasi itu merupakan hal yang penting bagi organisasi terutama untuk menjaga kelangsungan dan pencapaian tujuan. Namun, untuk memperoleh komitmen yang tinggi, diperlukan kondisi-kondisi yang memadai untuk mencapainya. Komitmen sampai level afektif dan passion ini tentunya tidak didapatkan secara gratis karena sesungguhnya bermula dari kemudahan, konsistensi dan kejelasan sistem dan prosedur dalam organisasi. Kejelasan aturan main menjadikan pegawai bisa mengandalkan dan berpegang pada aturan. Dalam perkembangannya, seorang pegawai dapat menjadi dan akan bisa tahu di mana ia bisa ikut bermain dan menikmati pekerjaannya, bahkan memperbaiki kinerjanya dari waktu ke waktu. Hanya dalam tingkatan inilah komitmen pegawai dalam suatu organisasi bisa terasa oleh masyarakat umum, sehingga pada akhirnya masyarakat umum pun yakin akan kinerja dari orgganisasi tersebut.

Hubungan antara para pegawai dengan organisasi tempat kerjanya merupakan sesuatu yang dinamis. Hubungan tersebut senantiasa berubah karena masing-masing pihak menyesuaikan harapan-harapannya dengan yang lain, dan kontribusi-kontribusi yang ingin diberikannya kepada yang lain sebagai gantinya.

Kedisiplinan menjadi suatu syarat untuk mencapainya hasil yang optimal dalam 
organisasi baik organisasi dalam bentuk formal maupun non formal, sehingga dalam setiap peraturan di instansi atau perusahaan apapun mengenai kedisiplinan pasti selalu ada, hal ini disebabkan karena pentingnya pengaruh kedisiplinan dalam pencapaian standar-standar organisasi. Oleh karena itu, kedisiplinan sering menjadi suatu ukuran yang bernilai positif dan biasanya dijadikan indikasi seseorang yang sukses dalam mencapai cita-citanya dan mencapai tujuan organisasinya.

Ini dikarenakan untuk mencapai suatu kinerja yang tinggi bukanlah hal yang mudah utuk dilaksanakan. Oleh sebab itu, faktor yang sangat penting untuk mencapai kinerja yang tinggi adalah dengan adanya pelaksanaan disiplin kerja dari para pegawai, karena hal tersebut merupakan salah satu faktor penentu bagi keberhasilan dan kemajuan dalam mencapai tujuan yang ada. Dengan kata lain, tindakan disiplin digunakan oleh organisasi untuk menghukum para pegawai karena pelanggaran atas aturan-aturan kerja atau harapan-harapan organisasi.

Dengan demikian, dapat dikatakan bahwa komitmen dan disiplin kerja dari seorang pegawai maupun pegawai dalam suatu perusahaan maupun lembaga turut serta dalam mempengaruhi kinerja pegawai selain adanya pengaruh dari budaya organisasi itu sendiri. Ini dikarenakan, tanpa adanya komitmen kerja yang tinggi dan disiplin kerja yang maksimal dalam menerima ataupun melaksanakan pekerjaannya, maka tidak mungkin aktivitas yang akan maupun yang telah dijalani tidak akan pernah mencapai tingkatan yang maksimal.
Mengingat capaian target program kerja yang tercantum dalam LAKIP tersebut merupakan gambaran kinerja suatu institusi yang dalam hal ini adalah Dinas Perhubungan Provinsi Jambi, maka sesuai dengan petunjuk pelaksanaan evaluasi akuntabilitas kinerja instansi pemerintah yang dikeluarkan oleh Kementrian Negara Pendayagunaan Aparatur Negara Republik Indonesia melalui Deputi Bidang Akuntabilitas Aparatur tahun 2010, dapatlah disebutkan bahwa kinerja Dinas Perhubungan Provinsi Jambi tersebut dapat digolongkan rendah, karena kurang dari 90\%. secara teori banyak aspek yang menyebabkan tinggi rendahnya kinerja suatu organisasi, namun dalam hal ini, rendahnya kinerja Dinas Perhubungan Provinsi Jambi bisa bersumber dari internal organisasi maupun yang bersumber dari eksternal organisasi.

Sementara itu, dari hasil survei pada kantor Dinas Perhubungan Provinsi Jambi ini juga teridentifikasi beberapa aspek kelemahan yang berkaitan dengan kinerja, diantaranya seperti masih rendahnya disiplin kerja pegawai. Beberapa indikasi yang dapat ditunjukkan tentang masih rendahnya disiplin kerja pegawai Dinas Perhubungan Provinsi Jambi adalah terlihat dari masih banyaknya dijumpai para pegawai yang terlambat masuk kantor pada jam kerja dan pulang meninggalkan kantor lebih awal dari waktu yang seharusnya.

Dengan demikian, variabel-variabel independen seperti komitmen dan disiplin yang ada pada diri seorang pegawai sangat mempengaruhi bagi peningkatan maupun penurunan kinerja para pegawai ke depannya, terlebih pada para pegawai yang 
ada di Dinas Perhubungan Provinsi Jambi. Tentu saja, masalah ini tidak dapat dipandang dengan sebelah mata. Apabila hal tersebut sampai terjadi, maka tidak mungkin kinerja Dinas Perhubungan Provinsi Jambi di mata masyarakat akan menurun, dan akan menimbulkan pertanyaan-pertanyaan sebenarnya apa saja yang dilakukan oleh para pegawai di dinas maupun instansi pemerintahan tersebut.

Berdasarkan uraian di atas, maka peneliti tertarik untuk menuangkan hasil pemikiran dalam bentuk penelitian, dan pembuktian secara empiris tentang Pengaruh Komitmen dan Disiplin Terhadap Kinerja Pegawai Pada Dinas Perhubungan Provinsi Jambi.

\section{TINJAUAN PUSTAKA}

\section{Komitmen}

Organisasi tentu memiliki berbagai visi, misi dan tujuan, meskipun tidak terlepas adanya perilaku dari organisasi itu sendiri. Dalam perilaku organisasi, terdapat beragam definisi tentang komitmen. Sebagai suatu sikap, Riswanto (2010:1) yang menyatakan komitmen organisasi merupakan "sikap yang merefleksikan loyalitas karyawan pada organisasi dan proses berkelanjutan di mana anggota organisasi mengekspresikan perhatiannya terhadap organisasi dan keberhasilan serta kemajuan yang berkelanjutan."

Menurut

Robbins

(2008:2)

mendefinisikan komitmen organisasi, "bahwa keterlibatan pekerjaaan yang tinggi berarti memihak pada pekerjaan tertentu seseorang individu, sementara komitmen organisasional yang tinggi berarti memihak organisasi yang merekrut individu tersebut".
Sementara, menurut Strancock (2008:33), komitmen organisasi (organisational commitment) adalah "sikap yang mencerminkan sejauh mana seseorang individu mengenal dan terikat pada organisasinya. Seseorang individu yang memiliki komitmen tinggi kemungkinan akan melihat dirinya sebagai anggota sejati organisasi".

Berdasarkan beberapa uraian di atas, maka dapat disimpulkan bahwa komitmen dalam berorganisasi adalah sebagai suatu keadaan dimana seseorang pegawai memihak organisasi tertentu serta tujuan dan keinginannya untuk mempertahankan keanggotaan dalam organisasi tersebut.

Robbins, (2008:9) mengemukakan terdapat 5 (lima) indikator-indikator yang berpengaruh terhadap komitmen dalam berorganisasi, antara lain sebagai berikut :

1. Budaya keterbukaan.

2. Kepuasan kerja.

3. Kesempatan personal untuk berkembang.

4. Arah organisasi.

5. Penghargaan kerja yang sesuai dengan kebutuhan.

Sementara, menurut Riswanto (2010:2), mengemukakan komitmen organisasional memiliki indikator-indikator, antara lain sebagai berikut :

1. Kemauan karyawan.

2. Kesetiaan karyawan.

3. Kebanggaan karyawan pada organisasi.

Komitmen pegawai pada organisasi tidak terjadi begitu saja, tetapi melalui proses yang cukup panjang dan bertahap. Komitmen pegawai pada organisasi juga ditentukan oleh sejumlah faktor. Robbins, (2008:8) mengidentifikasi ada 3 (tiga) faktor- 
faktor yang mempengaruhi komitmen pegawai pada organisasi, antara lain sebagai berikut :

1. Ciri pribadi pekerja, termasuk masa jabatannya dalam organisasi, dan variasi, kebutuhan dan keinginan yang berbeda dari tiap pegawai.

2. Ciri pekerjaan, seperti identitas tugas dan kesempatan berinteraksi dengan rekan sekerja.

3. Pengalaman kerja, seperti keterandalan organisasi di masa lampau dan cara pekerja-pekerja lain mengutarakan dan membicarakan perasaannya mengenai anisasi.

\section{Disiplin}

Menurut Handoko (2001:208), disiplin adalah "kegiatan manajemen untuk menjalankan standar-standar organisasional. Ada dua tipe kegiatan pendisiplinan yaitu preventif dan korektif. Dalam pelaksanaan disiplin, untuk memperoleh hasil seperti yang diharapkan, maka pemimpin dalam usahanya perlu menggunakan pedoman tertentu sebagai landasan pelaksanaan".

Sementara, menurut Hasibuan (2009:193) merumuskan bahwa disiplin adalah "kesadaran dan kesediaan seseorang mentaati semua peraturan dan norma-norma sosial yang berlaku. Kesadaran adalah sikap seseorang yang secara sukarela mentaati semua peraturan dan sadar akan tugas dan tanggung jawabnya, kesediaan adalah suatu sikap, tingkah laku, dan peraturan perusahaan, baik yang tertulis maupun tidak".

Berdasarkan beberapa definisi dari para ahli di atas, maka dapat disimpulkan bahwa disiplin itu sendiri diartikan sebagai kesediaan seseorang yang timbul dengan kesadaran sendiri untuk mengikuti peraturanperatuan yang berlaku dalam organisasi.

Menurut Hasibuan (2009:194) ada beberapa indikator yang dapat mempengaruhi tingkat kedisiplinan pegawai suatu organisasi diantaranya : 1) Tujuan dan Kemampuan, 2) Kepemimpinan, 3) Balas Jasa, 4) Keadilan, 5) Waskat, 6) Ketegasan, dan 7) Sanksi.

Menurut Sastrohadiwiryo (2001:293) tujuan utama mengadakan sanksi disiplin kerja bagi pegawai yang melanggar normanorma perusahaan adalah memperbaiki dan mendidik para pegawai yang melakukan pelanggaran disiplin. Sanksi atas pelanggaran disiplin yang dijatuhkan haruslah setimpal dengan pelanggaran disiplin yang dilakukan sehingga secara adil dapat diterima. Pada umumnya sebagai pegangan manajer meskipun tidak mutlak, tingkat dan jenis sanksi disiplin kerja terdiri atas sanksi disiplin berat, sanksi disiplin sedang, dan sanksi disiplin ringan.

\section{Kinerja Pegawai}

Menurut Fahmi (2010:2), menyatakan bahwa kinerja adalah "hasil yang diperoleh oleh suatu organisasi baik organisasi tersebut bersifat profit oriented dan non profit oriented yang dihasilkan selama satu periode waktu".

Menurut Sedarmayanti (2007:260), mengemukakan kinerja adalah "hasil kerja yang dapat dicapai oleh seseorang atau sekelompok orang dalam suatu organisasi, sesuai dengan wewenang dan tanggungjawab masing-masing, dalam rangka upaya mencapai tujuan organisasi bersangkutan 
secara legal, tidak melanggar hukum dan sesuai dengan moral maupun etika".

Dari uraian definisi di atas, dapat disimpulkan kinerja (performance) sebagai hasil kerja yang dicapai oleh seseorang atau kelompok (organisasi) dalam waktu tertentu. Dalam beberapa literatur, istilah kinerja dikenal pula dengan istilah prestasi kerja, dimana prestasi kerja ini merupakan proses dengannya organisasi mengevaluasi pelaksanaan kerja individu. Adapun output yang dihasilkan dapat berupa fisik maupun non-fisik. Untuk mengetahui kinerja pegawai, maka perlu diadakan penilaian terhadap kinerja itu sendiri, dari penilaian itu dapat diketahui apakah kinerja yang dihasilkan oleh pegawai telah memenuhi standar atau tidak.

Dengan melakukan penilaian kinerja pegawai, pihak organisasi dapat memperoleh informasi tentang kinerja pegawai yang dapat digunakan oleh organisasi untuk memperbaiki kinerja pegawai, untuk lebih memotivasi pegawai agar mau mengembangkan diri, serta sebagai dasar perencanaan dan pengambilan keputusan.

Menurut Rachmawati (2007:124-125), adapun manfaat evaluasi prestasi/kinerja adalah : 1) Meningkatkan prestasi karyawan, 2) Standar kompensasi yang layak, 3) Penempatan karyawan, 4) Pelatihan dan pengembangan, 5) Jenjang karier, 6) Penataan staf, 7) Minimnya data informasi, 8) Kesalahan desain pekerjaan, 9) Peluang kerja yang adil, dan 10) Tantangan eksternal.

Sementara, menurut Fahmi (2010:66), menjelaskan bahwa penilaian kinerja dimanfaatkan oleh manajemen untuk :
1. Mengelola operasi organisasi secara efektif dan efisien melalui pemotivasian karyawan secara maksimum.

2. Membantu pengambilan keputusan yang bersangkutan dengan karyawan, seperti promosi, transfer, dan pemberhentian.

3. Mengidentifikasikan kebutuhan pelatihan dan pengembangan karyawan dan untuk menyediakan kriteria seleksi dan evaluasi program pelatihan karyawan.

4. Menyediakan umpan balik bagi karyawan mengenai bagaimana atasan mereka menilai kinerja mereka.

5. Menyediakan suatu dasar bagi distribusi penghargaan.

\section{METODE PENELITIAN}

Adapun yang menjadi objek penelitian adalah Dinas Perhubungan Provinsi Jambi dengan unit analisisnya adalah Pegawai Dinas Perhubungan Provinsi Jambi yang berjumlah 160 orang, yang terdiri dari 110 orang laki-laki dan 50 orang perempuan.

Penelitian ini menggunakan metode penelitian deskriptif dan verifikatif. Deskriptif yang oleh Oei (2010:26-27) dijelaskan sebagai suatu metode yang bertujuan untuk menggambarkan sesuatu dan berperan untuk mengungkapkan informasi yang menggambarkan seberapa besar tingkat variabel secara keseluruhan. Sedangkan, metode verifikatif menurut Ali (2010:65) adalah untuk mengetahui hubungan antar variabel melalui suatu pengujian hipotesis berdasarkan data yang dikumpulkan di lapangan. Adapun alat analisis yang digunakan dalam penelitian ini adalah alat analisis regresi linear berganda (multiple regression analysis). 
Sementara, dalam penelitian ini menggunakan 2 (dua) data yaitu data primer dan data sekunder dengan pengolahan data melalui uji validitas dan reliabilitas, serta uji normalitas, uji homogenitas, maupun koefisien determinasi dalam menentukan pengaruh variabel lain dalam penggunaan variabel komitmen dan disiplin terhadap kinerja pegawai pada Dinas Perhubungan Provinsi Jambi.

\section{HASIL DAN PEMBAHASAN Analisis Deskriptif}

Analisis ini bertujuan untuk menggambarkan masing-masing variabel ke dalam tabel distribusi frekuensi, kemudian dilakukan analisis persentase serta memberikan interpretasi terhadap analisis tersebut. Dimana, dalam analisis deskriptif ini variabel yang digunakan adalah komitmen, disiplin dan kinerja pegawai Dinas Perhubungan Provinsi Jambi. Adapun uji analisis dalam penelitian ini dapat dilihat pada tabel, sebagai berikut :

Tabel 1. Distribusi Frekuensi Komitmen

\begin{tabular}{|l|c|c|c|c|}
\hline \multicolumn{1}{|c|}{ Indikator } & $\begin{array}{c}\text { No. } \\
\text { Item }\end{array}$ & $\begin{array}{c}\text { Rata- } \\
\text { rata }\end{array}$ & $\begin{array}{c}\text { TCR } \\
(\%)\end{array}$ & Kategori \\
\hline $\begin{array}{l}\text { Budaya } \\
\text { Keterbukaan }\end{array}$ & $1-2$ & 4,06 & 81,29 & Baik \\
\hline Kepuasan Kerja & $3-4$ & 4,19 & 83,87 & Baik \\
\hline $\begin{array}{l}\text { Kesempatan } \\
\text { Personal Untuk } \\
\text { Berkembang }\end{array}$ & $5-6$ & 4,48 & 89,52 & Baik \\
\hline Arah Organisasi & $7-8$ & 4,42 & 88,39 & Baik \\
\hline $\begin{array}{l}\text { Penghargaan } \\
\text { Kerja yang } \\
\text { Sesuai Dengan } \\
\text { Kebutuhan }\end{array}$ & $9-10$ & 4,26 & 85,16 & Baik \\
\hline \multicolumn{2}{|l|}{ Rata-rata Variabel } & $\mathbf{4 , 2 8}$ & $\mathbf{8 5 , 6 5}$ & Baik \\
\hline
\end{tabular}

Sumber: data Diolah

Berdasarkan tabel $1 \mathrm{di}$ atas, skor ratarata secara keseluruhan dari jumlah item pertanyaan tentang variabel komitmen pegawai pada Dinas Perhubungan Provinsi
Jambi dengan tingkat rata-rata per variabelnya sebesar 4,28. Angka ini menunjukkan bahwa skor pernyataan responden berada dalam kategori sangat sering dipengaruhi.

Tabel 2. Distribusi Frekuensi Disiplin

\begin{tabular}{|l|c|c|c|c|}
\hline \multicolumn{1}{|c|}{ Indikator } & $\begin{array}{c}\text { No. } \\
\text { Item }\end{array}$ & $\begin{array}{c}\text { Rata- } \\
\text { rata }\end{array}$ & $\begin{array}{c}\text { TCR } \\
(\%)\end{array}$ & Kategori \\
\hline $\begin{array}{l}\text { Tujuan dan } \\
\text { Kemampuan }\end{array}$ & $11-12$ & $\mathbf{4 , 2 9}$ & $\mathbf{8 5 , 8 1}$ & Baik \\
\hline Kepemimpinan & $13-14$ & $\mathbf{3 , 8 3}$ & $\mathbf{7 6 , 6 1}$ & Cukup Baik \\
\hline Balas Jasa & $15-16$ & $\mathbf{4 , 1 7}$ & $\mathbf{8 3 , 3 9}$ & Baik \\
\hline Keadilan & $17-18$ & $\mathbf{4 , 0 8}$ & $\mathbf{8 1 , 6 1}$ & Baik \\
\hline Waskat & $19-20$ & $\mathbf{4 , 4 0}$ & $\mathbf{8 7 , 9 0}$ & Baik \\
\hline Ketegasan & $21-22$ & $\mathbf{4 , 3 0}$ & $\mathbf{8 5 , 9 7}$ & Baik \\
\hline Sanksi & $23-24$ & $\mathbf{4 , 1 8}$ & $\mathbf{8 3 , 5 5}$ & Baik \\
\hline \multicolumn{2}{|r|}{ Rata-rata Variabel } & $\mathbf{4 , 1 8}$ & $\mathbf{8 3 , 5 5}$ & Baik \\
\hline
\end{tabular}

Sumber: data Diolah

Berdasarkan tabel 2 di atas, skor ratarata secara keseluruhan dari jumlah item pertanyaan tentang variabel disiplin pegawai pada Dinas Perhubungan Provinsi Jambi dengan tingkat rata-rata per variabelnya sebesar 4,18. Angka ini menunjukkan bahwa skor pernyataan responden berada dalam kategori sangat sering dipengaruhi.

Tabel 3. Distribusi Frekuensi

Kinerja Pegawai

\begin{tabular}{|l|c|c|c|c|}
\hline \multicolumn{1}{|c|}{ Indikator } & $\begin{array}{c}\text { No. } \\
\text { Item }\end{array}$ & $\begin{array}{c}\text { Rata } \\
\text {-rata }\end{array}$ & $\begin{array}{c}\text { TCR } \\
(\boldsymbol{\%})\end{array}$ & Kategori \\
\hline $\begin{array}{l}\text { Kemampuan } \\
\text { Mereka }\end{array}$ & $25-26$ & 4,13 & 82,58 & Baik \\
\hline Motivasi & $27-28$ & 4,17 & 83,39 & Baik \\
\hline $\begin{array}{l}\text { Dukungan yang } \\
\text { Diterima }\end{array}$ & $29-30$ & 4,26 & 85,16 & Baik \\
\hline $\begin{array}{l}\text { Keberadaan } \\
\text { Pekerjaan yang } \\
\text { Mereka Lakukan }\end{array}$ & $31-32$ & 4,12 & 82,42 & Baik \\
\hline $\begin{array}{l}\text { Hubungan Mereka } \\
\text { dengan Organisasi }\end{array}$ & $33-34$ & 4,34 & 86,77 & Baik \\
\hline \multicolumn{2}{|c|}{ Rata-rata Variabel } & $\mathbf{4 , 2 0}$ & $\mathbf{8 4 , 0 6}$ & Baik \\
\hline
\end{tabular}

Sumber: data Diolah

Berdasarkan tabel 3 di atas, skor ratarata secara keseluruhan dari jumlah item pertanyaan tentang variabel komitmen pegawai pada Dinas Perhubungan Provinsi Jambi dengan tingkat rata-rata per 
variabelnya sebesar 4,28. Angka ini menunjukkan bahwa skor pernyataan responden berada dalam kategori sangat sering dipengaruhi

\section{Pengaruh Komitmen Terhadap Kinerja Pegawai}

Dari hasil analisis yang dilakukan, melalui penggunaan software SPSS 19 terutama pada tabel correlation diperlihatkan bahwa besarnya pengaruh variabel komitmen terhadap kinerja pegawai Dinas Perhubungan Provinsi Jambi adalah sebesar 3,879 atau sebesar $39 \%$. Apakah pengaruh ini signifikan atau tidak dapat pula dilihat dari angka signifikan yaitu sebesar 0,000 yang jauh lebih kecil dari angka alpha sebesar 5 $\%$. Artinya, komitmen berpengaruh positif terhadap kinerja pegawai Dinas Perhubungan Provinsi Jambi.

Sebagai pembuktian lain untuk melihat tingkat signifikan koefisien regresi yang diperoleh ternyata dari hasil pengujian secara parsial (uji t) diperoleh nilai t-hitung untuk variabel komitmen adalah 3,879 yang jauh lebih besar dari nilai tabel pada alpha $5 \%$. Angka ini membuktikan bahwa koefisien regresi yang diperoleh signifikan atau komitmen benar berpengaruh secara signifikan terhadap kinerja pegawai Dinas Perhubungan Provinsi Jambi.

Ini sesuai dengan yang dirumuskan oleh Robbins (2008:79) yang menyatakan bahwa indikator-indikator seperti Budaya Keterbukaan, Kepuasan Kerja, Kesempatan Personal Untuk Berkembang, Arah Organisasi dan Penghargaan Kerja Yang Sesuai Dengan Kebutuhan sangat mempengaruhi seorang pegawai untuk berkemauan tinggi dalam berusaha untuk organisasi dan berkeyakinan kuat dalam menerima nilai-nilai dan tujuan-tujuan dalam suatu organisasi tersebut.

\section{Pengaruh Disiplin Terhadap Kinerja Pegawai}

Dari hasil analisis yang dilakukan di atas melalui penggunaan software SPSS 19 terutama pada tabel correlation diperlihatkan bahwa besarnya pengaruh variabel disiplin terhadap kinerja pegawai Dinas Perhubungan Provinsi Jambi adalah sebesar 2,811 atau sebesar $28 \%$. Apakah pengaruh ini signifikan atau tidak dapat pula dilihat dari angka signifikan yaitu sebesar 0,000 yang jauh lebih kecil dari angka alpha sebesar 5 $\%$. Artinya, disiplin berpengaruh positif terhadap kinerja pegawai Dinas Perhubungan Provinsi Jambi.

Sebagai pembuktian lain untuk melihat tingkat signifikan koefisien regresi yang diperoleh ternyata dari hasil pengujian secara parsial (uji t) diperoleh nilai t-hitung untuk variabel disiplin adalah 2,811 yang jauh lebih besar dari nilai tabel pada alpha $5 \%$. Angka ini membuktikan bahwa koefisien regresi yang diperoleh signifikan atau disiplin benar berpengaruh secara signifikan terhadap kinerja pegawai Dinas Perhubungan Provinsi Jambi.

Ini sesuai dengan yang dirumuskan oleh Hasibuan (2002:195) yang menyatakan bahwa indikator-indikator seperti Tujuan dan Kemampuan, Kepemimpinan, Balas Jasa, Keadilan, Waskat, Ketegasan dan Sanksi sangat mempengaruhi seorang pegawai untuk bersedia dalam mengikuti peraturanperaturan yang berlaku dalam organisasi tersebut. 


\section{Pengaruh Komitmen dan Disiplin Terhadap Kinerja Pegawai}

Berdasarkan hasil analisis diperoleh suatu model estimasi regresi linear berganda adalah $\mathrm{Y}=25,069+0,338 \mathrm{X}_{1}+0,240 \mathrm{X}_{2}$. Hasil analisis model estimasi regresi linear berganda diperoleh nilai konstanta sebesar 25,069. Hal ini menunjukkan bahwa tanpa adanya komitmen dan disiplin pegawai pada Dinas Perhubungan Provinsi Jambi telah mencapai 25,069. Artinya, bagi pegawai Dinas Perhubungan Provinsi Jambi, faktorfaktor tersebut menjadi penting atau tidak penting untuk menentukan kelancaran aktivitas dan tugas-tugas pada dinas tersebut.

Sebagai pembuktian lain untuk melihat tingkat signifikan koefisien regresi yang diperoleh ternyata dari hasil pengujian secara parsial (uji t) diperoleh nilai t-hitung untuk variabel komitmen adalah 3,879 yang jauh lebih besar dari nilai tabel pada alpha $5 \%$. Angka ini membuktikan bahwa koefisien regresi yang diperoleh signifikan atau komitmen dan disiplin benar berpengaruh secara signifikan terhadap kinerja pegawai Dinas Perhubungan Provinsi Jambi.

Ini sesuai dengan yang dirumuskan oleh Mathis \& Jackson (2001:82) yang menyatakan bahwa indikator-indikator seperti Kemampuan Pegawai, Motivasi, Dukungan Yang Diterima, Keberadaan Pekerjaan Yang Pegawai Lakukan, dan Hubungan Pegawai Dengan Organisasi sangat mempengaruhi seorang pegawai untuk berkemauan tinggi dalam berusaha untuk organisasi dan berkeyakinan kuat dalam menerima nilai-nilai dan tujuan-tujuan dalam suatu organisasi tersebut.

\section{PENUTUP \\ Kesimpulan}

Adapun hasil dalam penelitian ini menunjukkan bahwa terdapat pengaruh signifikan komitmen dan disiplin terhadap kinerja pegawai pada Dinas Perhubungan Provinsi Jambi. Dengan demikian, dapat dijelaskan bahwa kinerja pegawai tidak hanya dipengaruhi oleh beberapa faktor yang terdapat dalam diri pribadi atau individu pegawai dalam melaksanakan tugas mereka, melainkan juga terdapat faktor-faktor yang berasal dari luar dan dapat mempengaruhi tanggung jawab kerja para pegawai.

\section{Saran}

Adapun saran yang dapat dikemukakan dalam penelitian ini, antara lain sebagai berikut :

1. Mengingat komitmen berdasarkan perhitungan statistik dan hasil analisis terbukti mempunyai pengaruh yang paling dominan terhadap kinerja pegawai Dinas Perhubungan Provinsi Jambi, maka komitmen yang ada pada diri seorang pegawai Dinas Perhubungan Provinsi Jambi harus lebih ditingkatkan ke arah yang lebih baik lagi untuk menjaga kelangsungan dan pencapaian tujuan dari instansi maupun organisasi itu sendiri. Peningkatan kinerja melalui komitmen ini dapat dilakukan dengan kesepakatan reward dan cost antara kedua belah pihak, yang dapat dilakukan melalui adanya budaya keterbukaan, kepuasan kerja, kesempatan personal untuk berkembang, arah organisasi dan penghargaan kerja yang sesuai dengan kebutuhan.

2. Mengingat disiplin pegawai Dinas Perhubungan Provinsi Jambi termasuk kedalam kategori sedang dan dapat memberikan pengaruh menurunnya 
kinerja pegawai Dinas Perhubungan Provinsi Jambi secara keseluruhan, maka diperlukan adanya upaya untuk meningkatkan disiplin pegawai tersebut. Cara yang paling mungkin untuk pimpinan Dinas Perhubungan Provinsi Jambi itu sendiri adalah untuk menciptakan suatu kondisi dimana pegawai nantinya akan lebih memahami tujuan dan kemampuan dari instansi tempat mereka bekerja, memimpin dengan penuh tanggung jawab, memberikan balas jasa yang sesuai, bersikap adil kepada bawahan, pemberian waskat, serta adanya ketegasan dalam bertindak maupun memberikan sanksi kepada setiap pegawai yang lalai dalam menjalankan tugas tanpa memandang status maupun golongan dan jabatan pegawai tersebut.

\section{DAFTAR PUSTAKA}

Ali, Hapzi. 2010. Membangun Citra Perbankan Melalui IT \& CRM : Untuk Meningkatkan Loyalitas Nasabah. Yogyakarta : Hasta Cipta Mandiri.

Fahmi, Irfan. 2010. Manajemen Kinerja : Teori dan Aplikasi. Bandung : Alfabeta.

Hasibuan, S.P. 2009. Manajemen Sumber Daya Manusia. Jakarta : Bumi Aksara.

Oei, Istijanto. 2010. Riset Sumber Daya Manusia : Cara Praktis Mengukur Stres, Kepuasan Kerja, Komitmen, Loyalitas, Motivasi Kerja dan Aspekaspek Kerja Karyawan Lainnya. Edisi Revisi. Jakarta : PT. Gramedia Pustaka Utama.

Rachmawati, I. K. 2007. Manajemen Sumber Daya Manusia. Yogyakarta : ANDI.

Robbins, Stephen P. 2008. Essential of Organizational Behavior. Jakarta : Salemba Empat.
Santrock, John W. 2008. Educational Psychology. 2nd Edition. Terjemahan Tri Wibowo B.S. Jakarta : Prenada Media Group.

Sastrohadiwiryo, Siswanto. 2001. Manajemen Tenaga Kerja Indonesia. Jakarta : Bumi Aksara.

Sedarmayanti. 2007. Manajemen Sumber Daya Manusia : Reformasi Birokrasi dan Manajemen Pegawai Negeri Sipil. Bandung : PT. Refika Aditama. 